\title{
WORK ENGENDERED
}


This page intentionally left blank 


\section{Work Engendered}

Toward a New History

of American Labor

Edited by

Ava Baron

Cornell University Press

Ithaca and London 


\section{Copyright $\odot$ I99 I by Cornell University}

All rights reserved. Except for brief quotations in a review, this book, or parts thereof, must not be reproduced in any form without permission in writing from the publisher. For information, address Cornell University Press, Sage House, 5 I 2 East State Street, Ithaca, New York I 4850.

First published I99 I by Cornell University Press.

First printing, Cornell Paperbacks, 1991.

International Standard Book Number 0-801 4-2256-6 (cloth)

International Standard Book Number o-8014-9543-I (paper)

Library of Congress Catalog Card Number 9I-228I

Printed in the United States of America

Librarians: Library of Congress cataloging information

appears on the last page of the book.

Cornell University Press strives to utilize environmentally responsible suppliers and materials to the fullest extent possible in the publishing of its books. Such materials include vegetable-based, low-VOC inks and acid-free papers that are also either recycled, totally chlorine-free, or partly composed of nonwood fibers.

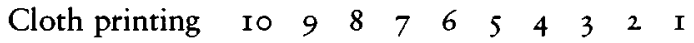

Paperback printing $\begin{array}{llllllll}\text { Io } & 9 & 8 & 7 & 6 & 5 & 4 & 3\end{array}$ 
FOR NOAH 
This page intentionally left blank 